\title{
Erratum: Recurrent synapses and circuits in the CA3 region of the hippocampus: an associative network
}

\section{Caroline Le Duigou, Jean Simonnet, Maria T. Teleńczuk, Desdemona Fricker and Richard Miles*}

Centre de Recherche de I'Institut du Cerveau et de la Moelle, INSERM U975, CHU Pitié-Salpêtrière, Université Pierre et Marie Curie, Paris, France

${ }^{*}$ Correspondence: richard.miles@upmc.fr

Edited and reviewed by:

Enrico Cherubini, International School for Advanced Studies, Italy

\section{Keywords: erratum}

\section{An erratum on}

Recurrent synapses and circuits in the CA3 region of the hippocampus: an associative network

by Le Duigou, C., Simonnet, J., Teleńczuk, M. T., Fricker, D., and Miles, $R$. (2014). Front. Cell. Neurosci. 7:262. doi: 10.3389/fncel.2013.00262

1. We should like to correct the name for one of the authors. Maria T.
Teleñczuk should be corrected to Maria T. Teleńczuk.

2. ACKNOWLEDGMENTS: Maria T. Teleńczuk would also like to acknowledge support from the Ecole des Neurosciences and the DIM Cerveau et Pensée (Paris, Ile de France).

Received: 24 January 2014; accepted: 03 February 2014; published online: 20 February 2014.

Citation: Le Duigou C, Simonnet J, Teleńczuk MT, Fricker D and Miles $R$ (2014) Erratum: Recurrent synapses and circuits in the CA3 region of the hippocampus: an associative network. Front. Cell. Neurosci. 8:48. doi: 10.3389/fncel.2014.00048

This article was submitted to the journal Frontiers in Cellular Neuroscience.

Copyright (c) 2014 Le Duigou, Simonnet, Teleńczuk, Fricker and Miles. This is an open-access article distributed under the terms of the Creative Commons Attribution License (CC BY). The use, distribution or reproduction in other forums is permitted, provided the original author(s) or licensor are credited and that the original publication in this journal is cited, in accordance with accepted academic practice. No use, distribution or reproduction is permitted which does not comply with these terms. 